\title{
Meta-analysis of the risk of cataract in type 2 diabetes
}

Li Li ${ }^{1 *}$ Xiu-hua Wan² and Guo-hong Zhao ${ }^{2}$

\begin{abstract}
Background: This meta-analysis aimed to investigate the association between type 2 diabetes (T2D) and the risk of cataract.

Methods: Databases of Pubmed, Embase, and SpringerLink were retrieved for observational studies published before November 2013. The odds ratio (OR) and 95\% confidence interval (Cl) were used for estimating the association. All statistical analyses were performed by Stata 10.0 software.

Results: A total of 8 studies involving 20837 subjects were included in the meta-analysis. The risk of any cataract (AC) in T2D patients was higher than that in non-diabetic subjects $(\mathrm{OR}=1.97,95 \% \mathrm{Cl}: 1.45-2.67, P<0.001)$. The risks of cortical cataract posterior (CC) (OR $=1.68,95 \% \mathrm{Cl}: 1.47-1.91, P<0.001)$ and posterior subcapsular (PSC) $(\mathrm{OR}=1.55$, 95\% Cl: 1.27-1.90, $P<0.001)$ were significantly elevated in T2D patients, while no significant association was found in nuclear sclerosis (NS) (OR $=1.36,95 \% \mathrm{Cl}: 0.97-1.90, P=0.070)$.
\end{abstract}

Conclusion: T2D patients had a higher risk of cataracts, excepting NS. Special attention should be paid on the ophthalmic extermination, especially for cataract in T2D patients.

Keywords: Non-diabetic, Nuclear sclerosis, Ophthalmology

\section{Background}

Cataract, a loss of the normal transparency of the crystalline lens due to an opacity (lens opacity or crystalline opacity), is one of the leading causes of blindness worldwide $[1,2]$. Hence, identification of the risk factors is of great importance for prevention and treatment of the blindness. Pollreisz [3] propose in a review article that diabetes is one of the widely perceived risk factors for cataract. Diabetes patients are more prone to develop cataracts [2]. The cataract incidence was estimated 3.31 per 1000 person-years of type 2 diabetic patients during 3.6 years' follow-up [4]. However, studies [5-8] found that not all types of cataracts [9], nuclear sclerosis (NS), cortical cataract (CC) or posterior subcapsular (PSC), are more prone to occurring in type 2 diabetes (T2D) patients. Evidence for their association has not been systematically assessed.

\footnotetext{
*Correspondence: Iliilili2@hotmail.com

'Department of Ophthalmology, The Affiliated Beijing Children's Hospital of Capital Medical University; National Key Discipline of Pediatrics, Ministry of Education, Beijing 100045, China

Full list of author information is available at the end of the article
}

Therefore, we performed this meta-analysis to explore the association between T2D and the risk of cataract. We anticipate the findings of this study will provide reliable evidence for clinical cataract research and prevention.

\section{Methods \\ Search strategy}

The databases included PubMed, Embase and SpringerLink and the studies had to be published before November 2013. Only the articles written in English were screened. The key words were consisted of three parts: 1) cataract OR lens opacity OR crystalline opacity; 2) diabetes OR T2DM OR type 2 diabetes; 3 ) risk OR incidence.

\section{The eligible criteria \\ Inclusion criteria were: (1) the study was designed as observational study (cross-sectional, case-control or cohort study); (2) the study explored the relationship between T2D and the risk of cataracts; (3) there was control group; (4) the outcomes include incidence of cataracts (AC, CC, NS and PSC); (5) the study provided}


enough information for calculating the Odds Ratio (OR) and $95 \%$ confidence interval (CI); (6) if there were multiple articles with same population or data, only the article with the longest follow-up and complete data was selected.

Exclusion criteria were: (1) the study with type 1 diabetes mellitus patients was excluded; (2) all duplicates were excluded; and (3) review articles, letters and comments were also excluded.

\section{Study selection and quality assessment}

Two investigators independently retrieved the eligible studies according to the search strategy and eligible criteria. The references were managed by Endnote software (Thomson ISI ResearchSoft, Carlsbad, CA, USA). Besides, the manual search was performed to retrieve some more eligible studies in the reviews and references of included studies. The quality of the selected studies were assessed by STROBE statement [10] including 22 items.

\section{Data extraction}

Study characteristics, including first author, publication year, study design, country, diagnosis of cataract and diabetes, age/gender of patient, were extracted independently by two researchers. The odds ratios (ORs) and $95 \%$ confidence intervals (CIs) of the exposures were extracted. The statistical methods of covariates adjustment were also noted. Any disagreement was resolved by discussion.

\section{Heterogeneity test}

The heterogeneity between studies was evaluated by $Q$ test [11] and $I^{2}$ statistics [12], where, $P>0.05$ and/or $I^{2}<50 \%$ was considered homogeneity, and a fixed-effect model was used for calculate pooled effect; otherwise, there was significant heterogeneity and random-effect model was used.

\section{Pooled analysis}

The meta-analysis was stratified for different types of cataract definition: AC, CC, NS and PSC. The pooled effect of each exposure on T2D was estimated by the values of ORs and 95\% CIs. If the ORs were provided in the publications, they were used for pooled estimate. Otherwise, the ORs were calculated according to the provided data in the articles. All statistical analyses were conducted by Stata 11.0 software.

\section{Sensitivity analysis and publication bias estimate}

The sensitivity analysis was conducted to test the robustness of the results by: 1) only the cross-sectional studies were included; 2 ) only the studies with Eye examination to confirm the cataract were included. The publication bias was estimated by Begg's test [13] and Egger's test [14], using a significance level of $P<0.05$ to indicate significant asymmetry.

\section{Results}

Study selection

The process of literature search and study selection was displayed in Figure 1. By retrieval of PubMed, Embase and SpringerLink databases according to the search strategy, 771, 238 and 677 documents were obtained, respectively. After excluding the duplicates, 1037 articles remained. By screening the title, we excluded 1014 documents that did not meet the inclusion criteria. Then by reading the abstracts 10 studies were excluded (3 without control group; 1 outcome was not incidence of cataract; 6 did not investigated the relationship between $\mathrm{T} 2 \mathrm{D}$ and cataract). Then in the remaining 13 studies, we reviewed the full text and 5 studies were excluded including 1 with non T2D subjects, 3 with incomplete data and 1 with duplicated crowd. Finally, 8 studies [5-7,15-19] were included in this meta-analysis.

\section{The characteristics of the included studies}

The characteristics of the included studies were listed in Table 1. All studies are with high quality (17-21 STROBE scores, Additional file 1: Table S1). Among the 8 include studies there were 6 cross-sectional studies [5-7,15,17,18], 1 cohort study [19] and 1 case-control study [16], including 20837 subjects. Since Jacques' study [5] did not provide the specific number of cases, so we could not obtain the accurate total number of cases in this meta-analysis. The area distributions of the 8 studies were: 2 in Europe (France and Sweden), 3 in American, 1 in African and one in Australian. Seven articles reported three kinds of outcomes of NS, CC

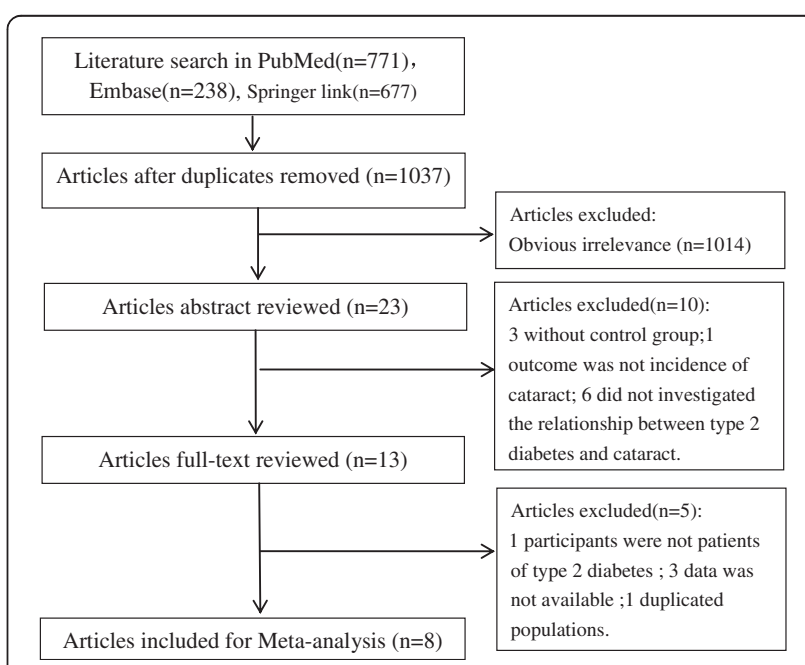

Figure 1 Literature search and study selection. 
Table 1 Characteristics of $\mathbf{8}$ studies on type $\mathbf{2}$ diabetes and cataract

\begin{tabular}{|c|c|c|c|c|c|c|c|c|c|c|c|c|c|c|}
\hline Author year & Location & $\begin{array}{l}\text { Ascertainment } \\
\text { of cataract }\end{array}$ & $\begin{array}{l}\text { Type of } \\
\text { study }\end{array}$ & $\begin{array}{l}\text { Ascertainment } \\
\text { of diabetes }\end{array}$ & $\begin{array}{l}\text { Definition } \\
\text { of cataract }\end{array}$ & Age(y) sex & Outcome & $\begin{array}{l}\text { No. of } \\
\text { case }\end{array}$ & Diabetes & $\begin{array}{l}\text { No. of } \\
\text { case }\end{array}$ & Non- diabetes & $\begin{array}{l}\text { ORs } \\
(95 \% \mathrm{Cl})\end{array}$ & $\begin{array}{l}\text { Adjustment for } \\
\text { covariates }\end{array}$ & $\begin{array}{l}\text { STROBE } \\
\text { scores }\end{array}$ \\
\hline \multirow[t]{4}{*}{$\begin{array}{l}\text { Machan } \\
2012[8]\end{array}$} & French & Hospital records & Cross- sectional & Hospital records & LOCS ॥ & $<1-93$ M\&F & $A C$ & 348 & 452 & 1885 & 5884 & $1.60(1.13,2.27)$ & $\begin{array}{l}\text { Age, gender, smoking, } \\
\text { systolic blood pressure, } \\
\text { Statin use }\end{array}$ & 20 \\
\hline & & & & & & & NS & 282 & & 1546 & & $1.62(1.14,2.29)$ & & \\
\hline & & & & & & & $\mathrm{CC}$ & 104 & & 525 & & $1.37(1.02,1.83)$ & & \\
\hline & & & & & & & PSC & 44 & & 194 & & $1.33(0.90,1.96)$ & & \\
\hline \multirow[t]{3}{*}{$\begin{array}{l}\text { Tan et al. } \\
2008[19]\end{array}$} & Australia & Eye examination & Cohort & $\begin{array}{l}\text { Medical record } \\
\text { or IFG test }\end{array}$ & $\begin{array}{l}\text { Wisconsin } \\
\text { Cataract } \\
\text { Grading } \\
\text { System }\end{array}$ & $\geq 49 \mathrm{M} \& \mathrm{~F}$ & NS & 37 & 69 & 402 & 1149 & $6.76(1.04,14.00)^{*}$ & $\begin{array}{l}\text { Age, gender, smoking, } \\
\text { myopia, and pulse } \\
\text { pressure, sun-related } \\
\text { skin damage, ever use } \\
\text { of steroids, myopia, and } \\
\text { body mass index }\end{array}$ & 21 \\
\hline & & & & & & & $\mathrm{CC}$ & 32 & 95 & 443 & 1642 & $1.60(0.78,4.87)^{*}$ & & \\
\hline & & & & & & & PSC & 15 & 112 & 162 & 1844 & $1.56(0.72,3.79)^{*}$ & & \\
\hline $\begin{array}{l}\text { Rotimi et al. } \\
2003 \text { [18] }\end{array}$ & West African & Eye examination & Cross- sectional & IFG test & - & $\geq 20 \mathrm{M} \& \mathrm{~F}$ & $A C$ & 373 & 831 & 35 & 191 & $3.63(2.45,5.37)^{*}$ & Crude & 18 \\
\hline \multirow[t]{4}{*}{$\begin{array}{l}\text { Olafsdottir et al. } \\
2012 \text { [7] }\end{array}$} & Sweden & Eye examination & Cross- sectional & IFG test & $\begin{array}{l}\text { LOCS } \| \\
\text { score } \geq 2\end{array}$ & 24-93y M\&F & $A C$ & 208 & 275 & 175 & 256 & $1.44(0.98,2.10)^{*}$ & Crude & 20 \\
\hline & & & & & & & NS & 132 & & 131 & & $0.88(0.63,1.24)^{*}$ & & \\
\hline & & & & & & & CC & 180 & & 131 & & $1.81(1.28,2.56)^{*}$ & & \\
\hline & & & & & & & PSC & 117 & & 83 & & $1.54(1.08,2.20)^{*}$ & & \\
\hline \multirow[t]{3}{*}{$\begin{array}{l}\text { Jacques et al. } \\
2003 \text { [5] }\end{array}$} & USA & Eye examination & Cross- sectional & IFG test & $\begin{array}{l}\text { LOCS III } \\
\geq 2.5, \mathrm{NS} ; \\
\geq 1.0, \mathrm{CC} \\
\geq 0.5, \mathrm{PSC}\end{array}$ & $54-73 \mathrm{~F}$ & NS & $N R$ & 31 & NR & 400 & $1.5(0.6,3.5)$ & $\begin{array}{l}\text { Age, smoking, } \\
\text { summertime sunlight } \\
\text { exposure, and alcohol } \\
\text { intake }\end{array}$ & 21 \\
\hline & & & & & & & $\mathrm{CC}$ & & & & & $1.2(0.6,2.6)$ & & \\
\hline & & & & & & & PSC & & & & & $4.1(1.8,9.4)$ & & \\
\hline \multirow[t]{3}{*}{$\begin{array}{l}\text { Klein et al. } \\
1995 \text { [6] }\end{array}$} & USA & Eye examination & Cross- sectional & $\begin{array}{l}\text { Medical record } \\
\text { or IFG test }\end{array}$ & $\begin{array}{l}\text { Wisconsin } \\
\text { Cataract } \\
\text { Grading } \\
\text { System }\end{array}$ & 43-84 M\&F & NS & 66 & 384 & 570 & 4285 & $0.93(0.67,1.29)$ & Age, gender & 17 \\
\hline & & & & & & & $\mathrm{CC}$ & 81 & & 471 & & $1.72(1.29,2.30)$ & & \\
\hline & & & & & & & PSC & 19 & & 165 & & $1.09(0.66,1.78)$ & & \\
\hline \multirow[t]{5}{*}{$\begin{array}{l}\text { Leske et.al. } \\
1999 \text { [16] }\end{array}$} & USA & Eye examination & Case- control & $\begin{array}{l}\text { Medical record } \\
\text { or IFG test }\end{array}$ & $\begin{array}{l}\text { LOCS } \| \\
\text { grade } \geq 2\end{array}$ & 40-84 M\&F & $A C$ & 1800 & 448 & 2431 & 289\# & $1.85(1.51,2.27)$ & Age, gender & 18 \\
\hline & & & & & & & NS & & 48 & & & $1.35(0.89,2.05)$ & & \\
\hline & & & & & & & CC & 229 & 201 & & & $1.74(1.39,2.18)$ & & \\
\hline & & & & & & & PSC & 851 & 4 & & & $1.88(0.61,5.79)$ & & \\
\hline & & & & & & & & 17 & & & & & & \\
\hline
\end{tabular}


Table 1 Characteristics of 8 studies on type 2 diabetes and cataract (Continued)

Foster et al. $\quad$ Singapore Eye examination Cross- sectional Medical record LOCS III 40-81 M\&F

2003 [15]

$\geq 4$ NS

$A C$

NR

27

NR

1066

$\geq 2$ for
CC $\geq 2$

$2.0(0.9,4.5)$

Age, gender, body

mass index and

for PSC

*: ORs was calculated based on literature data; AC: any cataract; NS: nuclear sclerosis; CC: cortical cataract; PSC: posterior subcapsular cataract; NR: not recorded; LOCS, lens opacities classification system \#: number of diabetes. 


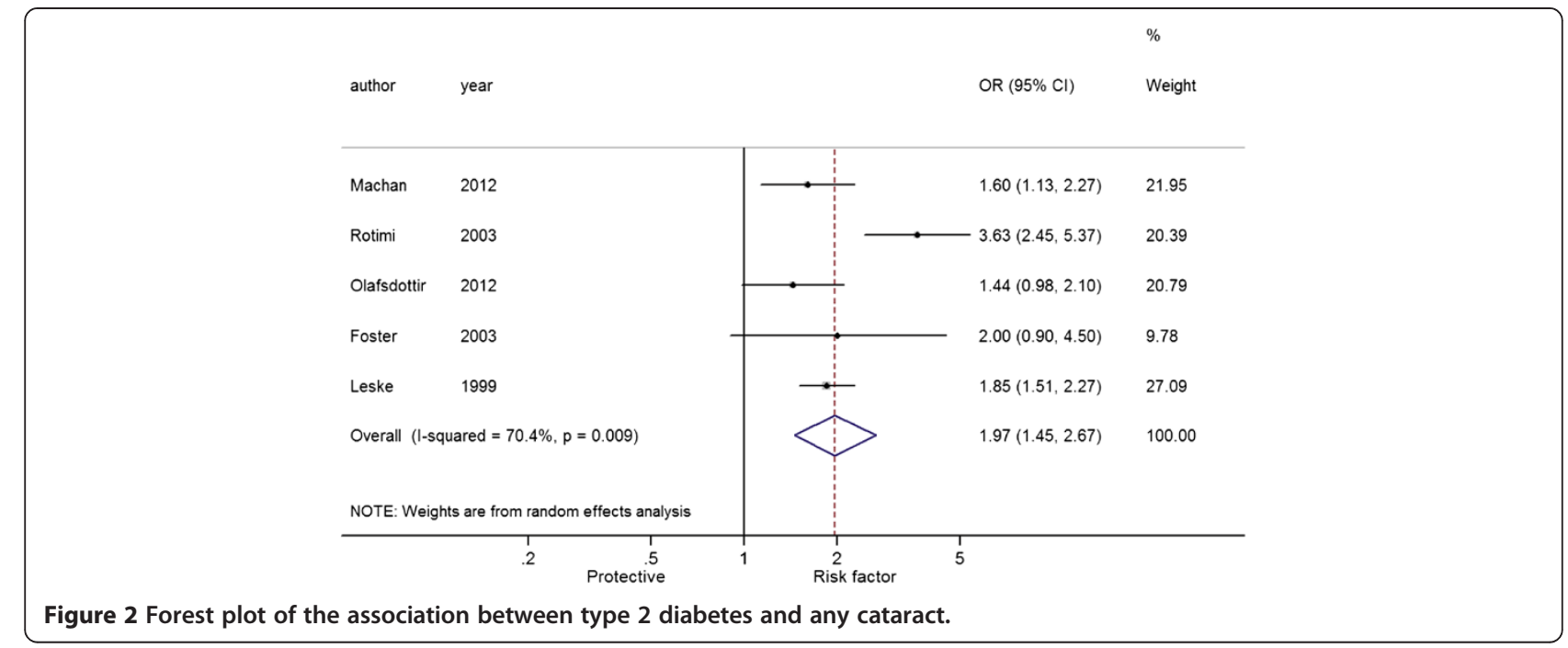

and PSC. Five studies reported the overall incidence of any cataract (AC). Six literatures provided adjusted OR and $95 \% \mathrm{CI}$, two studies provided OR calculable data.

\section{Meta-analysis of the risk of cataract in T2D patients}

By heterogeneity analysis of the five studies [7,15-18] that reported the overall incidence of $\mathrm{AC}$, there were significant heterogeneity among studies $\left(I^{2}=70.4 \%\right.$, $P=0.009$ ), and a random-effect model was used for estimate of the pooled effect. It was showed that (Figure 2) the OR of AC risk between T2D patients and non-diabetic subjects was 1.97 (95\% CI: 1.45-2.67, $P<0.001$ ), indicating that the risk of AC was significantly elevated in T2D patients compared with non-diabetic subjects.

Figures 3, 4 and 5 showed the pooled results of three types of cataract [5-7,15-17,19], NS, CC and PSC, in T2D patients. There was significant heterogeneity among studies of NS and T2D patients $\left(I^{2}=65.8 \%, P=0.007\right)$, and a random-effect model was used to produce an OR of 1.36 (95\% CI: 0.97-1.90, $P=0.070$ ), indicating a higher risk of NS in T2D patients over non-T2D patients. There was no significant heterogeneity among studies of CC $\left(I^{2}=3.3 \%, P=0.400\right)$ and PSC $\left(I^{2}=34.9 \%, P=0.162\right)$, and fixed-effect models were used. The pooled ORs were respectively 1.68 for CC (95\% CI: 1.47-1.91, $P<0.001)$ and 1.55 for PSC (95\% CI: $1.27-1.90, P<0.001)$. These results indicated that patients with $\mathrm{T} 2 \mathrm{D}$ had a higher risk of cataracts than those without.

\section{Sensitivity analysis and publication bias estimate}

The result of sensitivity analysis indicated that the results of the present meta-analysis were robust (Table 2). The

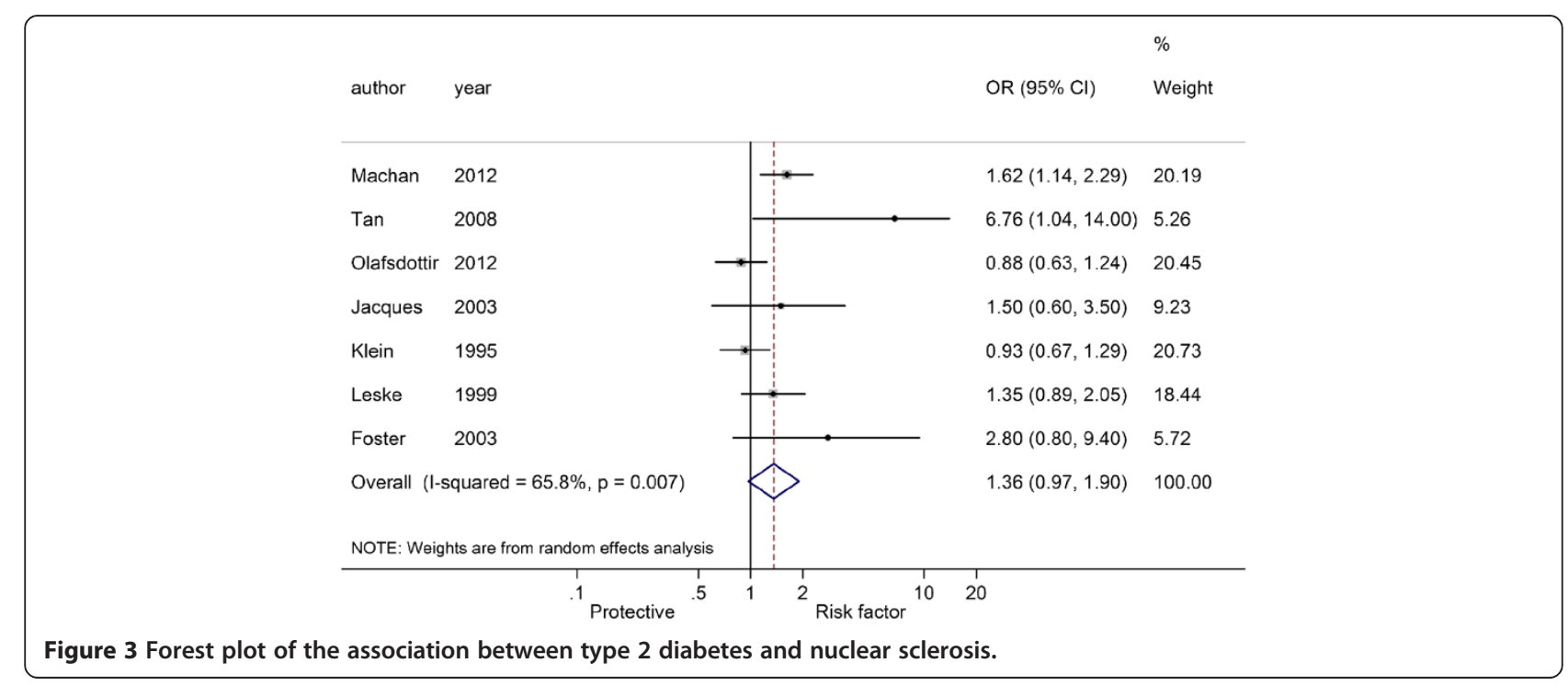




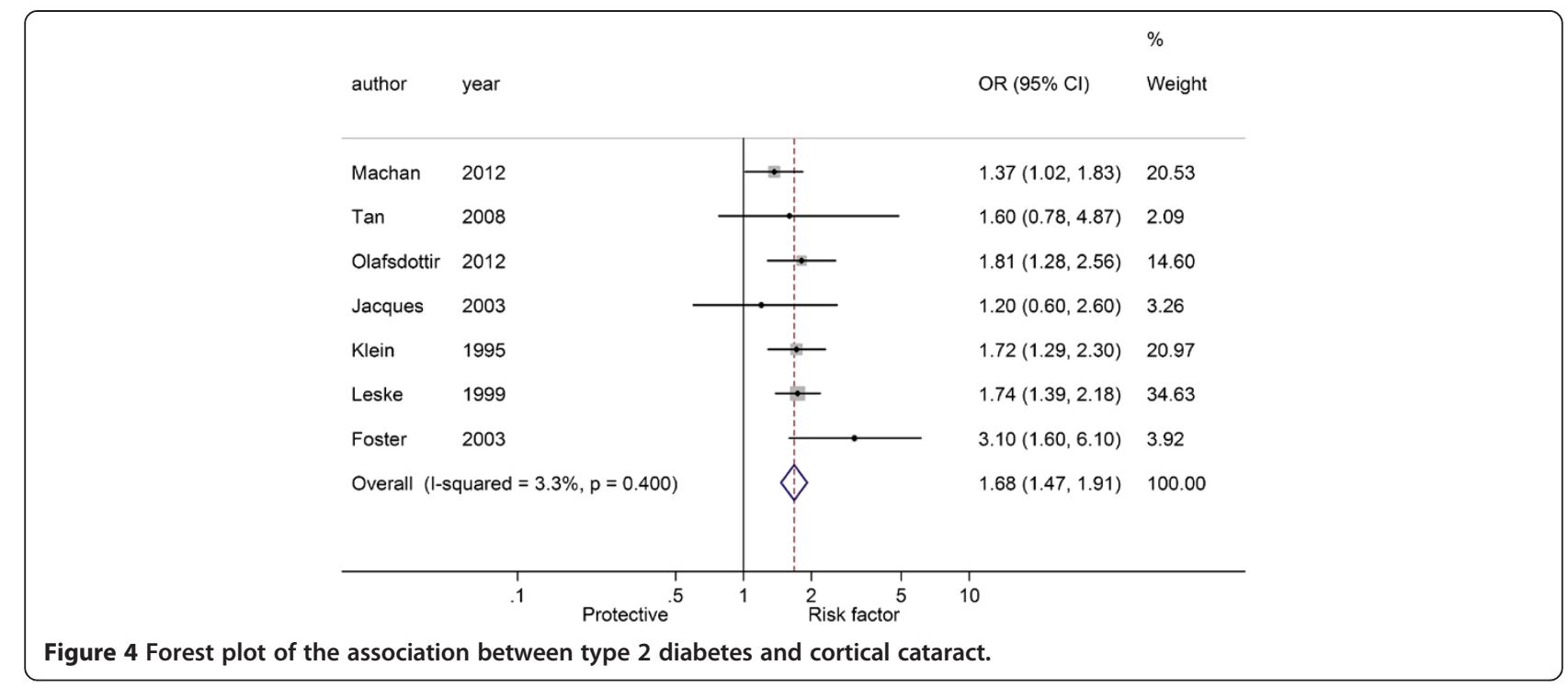

pooled results for the outcomes of cross-sectional studies or the studies with Eye examination for cataract diagnosis were consistent with those before sensitivity analysis.

Begg's test and Egger's test showed no significant publish bias among studies $(P>0.05$, Table 3$)$.

\section{Discussion}

Cataract is a major cause of blindness worldwide, and it largely results from occurrence of diabetes. The present meta-analysis with a substantial number of subjects (20837 subjects) indicated the risk of cataracts was elevated in T2D patients compared with the non-diabetic subjects.
It was reported that cataract is one of the most common complications of diabetes mellitus on the eye $[20,21]$ and up to $20 \%$ of all cataract procedures are performed for diabetic patients [22]. Cataracts were more frequently in patients with diabetes $[23,24]$. In the present study, approximate 2 times risk of AC was found in T2D patients compared with the non-diabetic subjects. Visual improvement was seen following extracapsular cataract extraction surgery for advanced cataract in diabetics and postoperative monitoring for treatment of diabetic retinopathy may enhance visual outcome [25].

A Waterloo Eye Study by reviewing of 6397 clinic files found that diagnosis of T2D resulted in an earlier development of all three cataract subtypes [8]. Similarly in the present study, we found that the risks of CC and PSC were

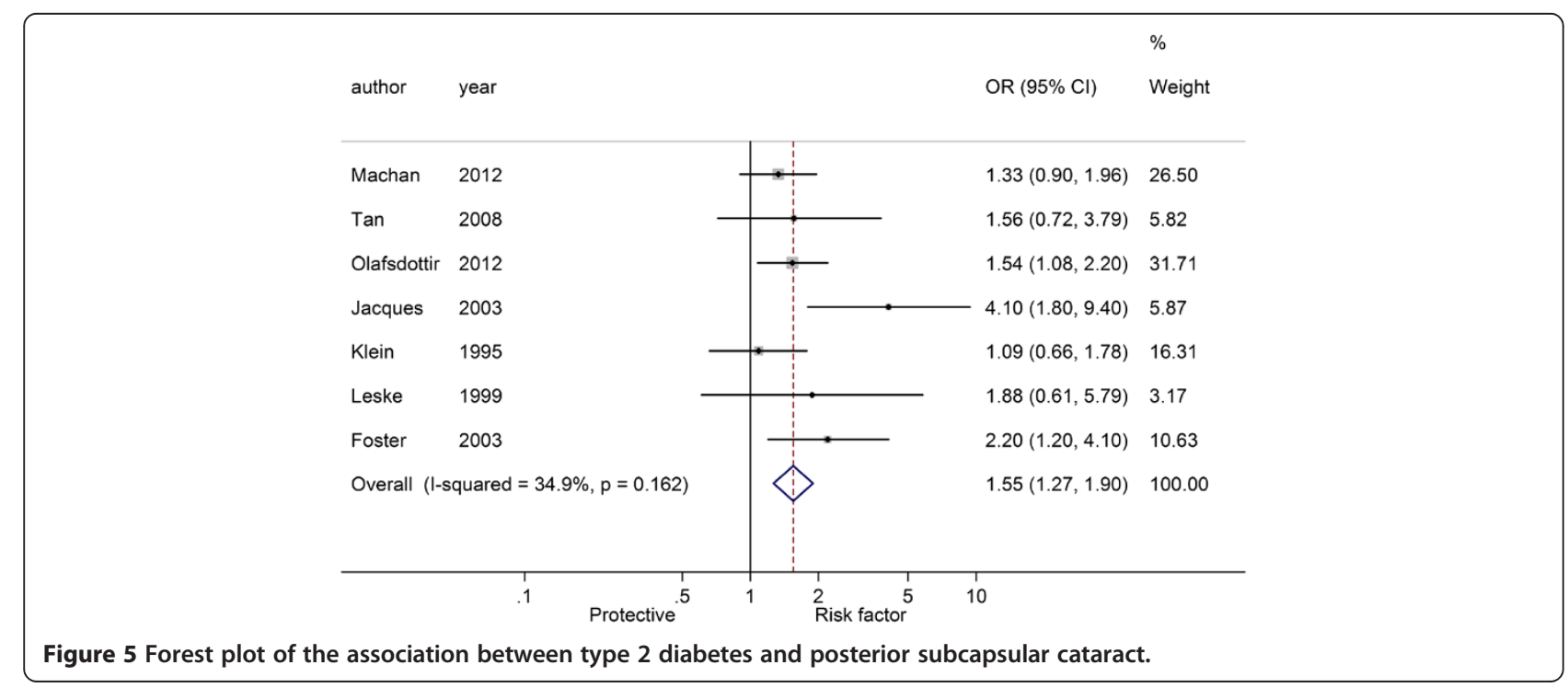


Table 2 Sensitivity analysis of meta-analysis of type 2 diabetes and cataract risks

\begin{tabular}{llllllllll}
\hline Outcomes & Pooled OR $(\mathbf{9 5 \%} \mathbf{C l})$ & $\boldsymbol{P}_{\mathbf{A}}$ & $\boldsymbol{P}_{\mathbf{H}}$ & \multicolumn{5}{c}{ Sensitivity analysis } \\
\cline { 6 - 10 } & & & & Cross-sectional study & $\boldsymbol{P}_{\mathbf{A}}$ & $\boldsymbol{P}_{\mathbf{H}}$ & Eye examination & $\boldsymbol{P}_{\mathbf{A}}$ & $\boldsymbol{P}_{\mathbf{H}}$ \\
\hline Any Cataract & $1.97(1.45,2.67)$ & $<0.001$ & 0.009 & $2.02(1.27,3.21)$ & 0.003 & 0.004 & $2.09(1.41,3.09)$ & $<0.001$ & 0.008 \\
NS & $1.36(0.97,1.90)$ & 0.070 & 0.007 & $1.20(0.86,1.69)$ & 0.288 & 0.040 & $1.31(0.89,1.93)$ & 0.164 & 0.017 \\
CC & $1.68(1.47,1.91)$ & $<0.001$ & 0.400 & $1.65(1.39,1.94)$ & $<0.001$ & 0.196 & $1.77(1.52,2.05)$ & $<0.001$ & 0.564 \\
PSC & $1.55(1.27,1.90)$ & $<0.001$ & 0.162 & $1.54(1.25,1.90)$ & $<0.001$ & 0.059 & $1.64(1.30,2.07)$ & $<0.001$ & 0.136 \\
\hline
\end{tabular}

$P_{\mathrm{A}}: P_{\text {value }}$ of association; $P_{\mathrm{H}}: P_{\text {value }}$ of Heterogeneity. AC: any cataract; NS: nuclear sclerosis; CC: cortical cataract; PSC: posterior subcapsular cataract.

elevated for patients with the T2D $(P<0.05)$. However, we did not find significant association between T2D and risk of NS. Olafsdottir [7] and Klein [6] reported rather different results about NS from other included studies, which are the main sources of the high heterogeneity, however, they draw similar conclusions in CC and PSC with other included studies. These results highlight the necessary of regular eye examination in T2D patients.

Klein et al. [26] indicated that glycemia may be the risk factor of cataracts in T2D patients. Three molecular mechanisms may be involved in the development of diabetic cataract: nonenzymatic glycation of eye lens proteins, oxidative stress, and activated polyol pathway in glucose disposition [27]. In addition, a genetic study showed that three single-nucleotide polymorphisms (SNPs) in chromosome 3p14.1-3p14.2 which related to functions of voltage-dependent anion-selective channel protein, long myosin light chain kinase, adenylyl cyclaseassociated protein, and retinoic acid receptor were significantly different in the T2D with cataracts and T2D without cataracts groups [28].

There were limitations in this meta-analysis. Although ORs were corrected by taking account of influences of age, sex and smoking in some included studies, the pooled results might also be influenced by other factors, for instance different treatments of T2D, regions of studies, and body mass index (BMI). Significant heterogeneity still exists among studies, which might be caused by the above factors. In addition, the different methods of definition of cataract (LOCS III, LOCS II, and Wisconsin Cataract Grading System) in deferent studies might also be an important source of heterogeneity.

Table 3 The results of publication bias estimate

\begin{tabular}{lll}
\hline & Begg's test & Egger's test \\
\hline AC & 0.806 & 0.790 \\
NS & 0.368 & 0.200 \\
CC & 1.000 & 0.906 \\
PSC & 0.368 & 0.198
\end{tabular}

Data were represented with $P$ value.

AC: any cataract; NS: nuclear sclerosis; CC: cortical cataract; PSC: posterior subcapsular cataract.

\section{Conclusion}

In summary, the present meta-analysis of five included studies involving 20837 subjects suggests that T2D is a risk factor of cataract, especially CC and PSC. The findings here attract attentions to the importance of regular ophthalmic extermination in T2D. However, the conclusions need more experimental verification.

\section{Additional file}

Additional file 1: Table S1. Methodological quality (STROBE Statementchecklist) of included studies in the meta-analysis.

\section{Competing interests}

The authors declare that they have no competing interests.

\section{Authors' contributions}

$\mathrm{LL}$ carried out the design and coordinated the study, participated in most of the experiments and prepared the manuscript. XW provide assistance in the design of the study, coordinated and carried out all the experiments and participated in manuscript preparation. GZ provided assistance for all experiments. All authors have read and approved the content of the manuscript.

\section{Author details}

1Department of Ophthalmology, The Affiliated Beijing Children's Hospital of Capital Medical University; National Key Discipline of Pediatrics, Ministry of Education, Beijing 100045, China. ${ }^{2}$ Beijing TongRen Eye Center, Beijing TongRen Hospital, Capital Medical University; Beijing Ophthalmology and Visual Sciences Key Laboratory, Beijing 100730, China.

Received: 15 May 2014 Accepted: 15 July 2014

Published: 24 July 2014

\section{References}

1. Thylefors B, Negrel A, Pararajasegaram R, Dadzie K: Global data on blindness. Bull World Health Organ 1995, 73(1):115.

2. JMJ R: Leading causes of blindness worldwide. Bull Soc Belge Ophtalmol 2002, 283:19-25.

3. Pollreisz A, Schmidt-Erfurth U: Diabetic cataract-pathogenesis, epidemiology and treatment. J Ophthalmol 2010, 2010:1-8.

4. Janghorbani $M$, Amini $M$ : Cataract in type 2 diabetes mellitus in Isfahan, Iran: incidence and risk factors. Ophthalmic Epidemiol 2004, 11(5):347-358.

5. Jacques PF, Moeller SM, Hankinson SE, Chylack LT Jr, Rogers G, Tung W, Wolfe JK, Willett WC, Taylor A: Weight status, abdominal adiposity, diabetes, and early age-related lens opacities. Am J Clin Nutr 2003, 78(3):400-405.

6. Klein BE, Klein R, Wang Q, Moss SE: Older-onset diabetes and lens opacities. The Beaver Dam Eye Study. Ophthalmic Epidemiol 1995, 2(1):49-55.

7. Olafsdottir E, Andersson DK, Stefansson E: The prevalence of cataract in a population with and without type 2 diabetes mellitus. Acta Ophthalmol 2012, 90(4):334-340. 
8. Machan CM: Type 2 diabetes mellitus and the prevalence of age-related cataract in a clinic population. Waterloo, Ontario, Canada: University of Waterloo; 2012.

9. Chylack LT, Wolfe JK, Singer DM, Leske MC, Bullimore MA, Bailey IL, Friend J, McCarthy D, Wu S-Y: The lens opacities classification system III. Arch Ophthalmol 1993, 111:1506.

10. Von Elm E, Altman DG, Egger M, Pocock SJ, Gøtzsche PC, Vandenbroucke JP: The Strengthening the Reporting of Observational Studies in Epidemiology (STROBE) statement: guidelines for reporting observational studies. Prev Med 2007, 45(4):247-251.

11. Lau J, loannidis JP, Schmid CH: Quantitative synthesis in systematic reviews. Ann Intern Med 1997, 127(9):820-826.

12. Higgins JP, Thompson SG, Deeks JJ, Altman DG: Measuring inconsistency in meta-analyses. BMJ 2003, 327(7414):557.

13. Begg CB, Mazumdar M: Operating characteristics of a rank correlation test for publication bias. Biometrics 1994, 50(4):1088-1101.

14. Egger M, Davey Smith G, Schneider M, Minder C: Bias in meta-analysis detected by a simple, graphical test. BMJ (Clin Res Ed) 1997, 315(7109):629-634.

15. Foster PJ, Wong TY, Machin D, Johnson GJ, Seah SK: Risk factors for nuclear, cortical and posterior subcapsular cataracts in the Chinese population of Singapore: the Tanjong Pagar Survey. Br J Ophthalmol 2003, 87(9):1112-1120.

16. Leske MC, Wu SY, Hennis A, Connell AM, Hyman L, Schachat A: Diabetes, hypertension, and central obesity as cataract risk factors in a black population. The Barbados Eye Study. Ophthalmology 1999, 106(1):35-41.

17. Machan CM, Hrynchak PK, Irving EL: Age-related cataract is associated with type 2 diabetes and statin use. Optom Vis Sci 2012, 89(8):1165-1171

18. Rotimi C, Daniel H, Zhou J, Obisesan A, Chen G, Chen Y, Amoah A, Opoku $V$, Acheampong J, Agyenim-Boateng K: Prevalence and determinants of diabetic retinopathy and cataracts in West African type 2 diabetes patients. Ethn Dis 2003, 13(2 Suppl 2):S110-S117.

19. Tan JS, Wang JJ, Mitchell P: Influence of diabetes and cardiovascular disease on the long-term incidence of cataract: the Blue Mountains eye study. Ophthalmic Epidemiol 2008, 15(5):317-327.

20. Ivancic D, Mandic Z, Barac J, Kopic M: Cataract surgery and postoperative complications in diabetic patients. Coll Antropol 2005, 29(Suppl 1):55-58.

21. Patel PM, Jivani N, Malaviya S, Gohil T, Bhalodia Y: Cataract: A major secondary diabetic complication. Int Curr Pharm 2012, 1(7):180-185.

22. Squirrell D, Bhola R, Bush J, Winder S, Talbot J: A prospective, case controlled study of the natural history of diabetic retinopathy and maculopathy after uncomplicated phacoemulsification cataract surgery in patients with type 2 diabetes. Br J Ophthalmol 2002, 86(5):565-571.

23. Klein $B E$, Klein R, Moss SE: Incidence of cataract surgery in the Wisconsin Epidemiologic Study of Diabetic Retinopathy. Am J Ophthalmol 1995, 119(3):295-300.

24. Obrosova IG, Chung SSM, Kador PF: Diabetic cataracts: mechanisms and management. Diabetes Metab Res Rev 2010, 26(3):172-180.

25. Onakpoya OH, Bekibele CO, Adegbehingbe SA: Cataract surgical outcomes in diabetic patients: case control study. Middle East Afr J Ophthalmol 2009, 16(2):88.

26. Klein BE, Klein R, Lee KE: Diabetes, cardiovascular disease, selected cardiovascular disease risk factors, and the 5-year incidence of age-related cataract and progression of lens opacities: the Beaver Dam Eye Study. Am J Ophthalmol 1998, 126(6):782-790.

27. Kyselova Z, Stefek M, Bauer V: Pharmacological prevention of diabetic cataract. J Diabetes Complicat 2004, 18(2):129-140,

28. Lin H-J, Huang Y-C, Lin J-M, Wu J-Y, Chen L-A, Lin C-J, Tsui Y-P, Chen C-P, Tsai F-J: Single-nucleotide polymorphisms in chromosome 3p14. 1-3p14. 2 are associated with susceptibility of Type 2 diabetes with cataract. Mol Vis 2010, 16:1206.

doi:10.1186/1471-2415-14-94

Cite this article as: Li et al:: Meta-analysis of the risk of cataract in type 2 diabetes. BMC Ophthalmology 2014 14:94.

\section{Submit your next manuscript to BioMed Central and take full advantage of:}

- Convenient online submission

- Thorough peer review

- No space constraints or color figure charges

- Immediate publication on acceptance

- Inclusion in PubMed, CAS, Scopus and Google Scholar

- Research which is freely available for redistribution

Submit your manuscript at www.biomedcentral.com/submit
() Biomed Central 